\title{
Proteomic analysis of oxidative modification in endothelial colony-forming cells treated by hydrogen peroxide
}

\author{
JUN WEI ${ }^{1,2^{*}}$, YING LIU $^{1 *}$, MING CHANG ${ }^{1}$, CHONG-LING SUN ${ }^{3}$, \\ DA-WEI LI ${ }^{1}$, ZHI-QIANG LIU ${ }^{1}$ and LIN-SEN HU ${ }^{1}$ \\ ${ }^{1}$ Department of Neurology, The First Hospital of Jilin University, Changchun; ${ }^{2}$ Department of Neurology, \\ Yichang Central People's Hospital, Yichang; ${ }^{3}$ Department of Rheumatology and Immunology, \\ Yichang Central People's Hospital, Yichang, P.R. China
}

Received January 4, 2012; Accepted February 22, 2012

DOI: $10.3892 / \mathrm{ijmm} .2012 .944$

\begin{abstract}
Endothelial progenitor cells (EPCs) which circulate in the peripheral blood and reside in blood vessels are proven to promote the repair of damaged endothelium and improve the function of endothelial cells after vascular injury. Recently, EPCs have been extensively studied as risk biomarkers and a potential therapeutic tool for cardiovascular disease. It is known that oxidative stress is one of the most important pathogenetic factors impairing endothelial function. During the repair process after endothelial injury, EPCs are exposed to oxidative stress. In this study, we treated endothelial colonyforming cells (ECFCs) with hydrogen peroxide $\left(\mathrm{H}_{2} \mathrm{O}_{2}\right)$ as an oxidative stress model and observed the changes in cytology and morphology of ECFCs. In addition, we investigated the alterations in oxidative levels of proteins associated with $\mathrm{H}_{2} \mathrm{O}_{2}$-induced morphological and cytological changes in ECFCs by proteomic analysis of oxidative modification. The results showed that $\mathrm{H}_{2} \mathrm{O}_{2}$ treatment led to a decreased proliferation, increased apoptosis and impaired tube-forming ability of ECFCs in a dose-dependent manner. Five proteins with upregulated oxidative levels were identified successfully. The upregulated oxidative levels of these five proteins may be responsible for the dysfunction of ECFCs under oxidative stress. Our results may provide some novel insights into the molecular mechanisms of oxidative stress action on ECFCs.
\end{abstract}

Correspondence to: Dr Lin-Sen $\mathrm{Hu}$, Department of Neurology, The First Hospital of Jilin University, Changchun 130021, P.R. China E-mail: hulinsen@hotmail.com

*Contributed equally

Abbreviations: EPCs, endothelial progenitor cells; ECFCs, endothelial colony-forming cells; $\mathrm{H}_{2} \mathrm{O}_{2}$, hydrogen peroxide; ROS, reactive oxygen species; PBS, phosphate-buffered saline; MTT, 3-(4,5-dimethylthiazole-2-yl)-2,5-diphenyltetrazolium bromide; DMSO, dimethyl sulfoxide; $\mathrm{AO} / \mathrm{EB}$, acridine orange/ethidium bromide; DNP, 2,4-dinitrophenylhydrazine; Prx4, peroxiredoxin-4; UT, untreated

Key words: endothelial progenitor cells, endothelial colony-forming cells, oxidative stress, proteomics

\section{Introduction}

The endothelium plays an important role in maintaining vascular tone and structure. The damage and dysfunction of endothelial cells are thought to trigger and accelerate the development of atherosclerosis $(1,2)$. Patients with endothelial dysfunction are also prone to cardiovascular events (3). Before Asahara et al (4) proposed the term of endothelial progenitor cells (EPCs), the adjacent endothelial cells were considered to be responsible for repairing the damaged endothelium. However, accumulating evidence indicates that EPCs are able to promote the repair of the damaged endothelium and improve the function of endothelial cells after vascular injury (5-7).

EPCs, which circulate in the peripheral blood and reside in blood vessels, have been demonstrated in both animal models and clinical trails to contribute to neovascularization, vascular repair and to attenuate atherosclerosis progression (8-11). Recently, EPCs have been extensively studied as risk biomarkers and a potential therapeutic tool for cardiovascular disease. Patients with vascular diseases, including stroke, coronary artery disease, hypertension and diabetes, have been shown to exhibit a reduced number and dysfunction of EPCs $(11,12)$. Improvement of endothelial function by reversal of EPC dysfunction may be a novel approach for restraining vascular diseases (13). Oxidative stress is one of the most important pathogenetic factors which impairs the endothelial function. Increasing generation of free radicals (reactive oxygen species, ROS) is the main characteristic of oxidative stress. ROS have been proven to exert a direct cytotoxic effect on the vascular endothelium (14). During the repair process after endothelial injury, EPCs are exposed to oxidative stress. Though some studies have suggested that the EPCs may be resistant to oxidative stress $(15,16)$, their results were considered to have limitations because the cell population used were mixed with macrophages and monocytes, which are known to be resistant to oxidative stress (17).

To overcome this problem, we used the endothelial colonyforming cells (ECFCs) for proteomics analysis. ECFCs are one of the subpopulations of EPCs and they do not express hematopoietic or monocyte/macrophage cell surface antigens. ECFCs have been shown to possess all the characteristics of true endothelial progenitor cells $(18,19)$. In this study, we 
treated the ECFCs with hydrogen peroxide $\left(\mathrm{H}_{2} \mathrm{O}_{2}\right)$ as an oxidative stress model and observed the changes in cytology and morphology of ECFCs. Then we investigated the variation in oxidative levels of proteins behind these changes by proteomics analysis of oxidative modification and discussed the roles of relevant proteins involved in the mechanisms of $\mathrm{H}_{2} \mathrm{O}_{2}$-induced oxidative stress on ECFCs.

\section{Materials and methods}

Cell culture. ECFCs (Lonza Walkersville, Inc., Walkersville, MD, USA) were resuspended in complete EGM-2 medium (Lonza Walkersville, Inc.), plated onto 75-cm tissue culture flasks precoated with type I rat tail collagen (BD Biosciences, Bedford, MA, USA) and incubated at $37^{\circ} \mathrm{C}$ with in $5 \% \mathrm{CO}_{2}$ and $90 \%$ humidity. ECFCs monolayers were passaged after becoming $70-80 \%$ confluent.

ECFCs proliferation assay. Proliferation of ECFC was measured by the 3-(4,5-dimethylthiazole-2-yl)-2,5-diphenyltetrazolium bromide (MTT) assay. Cells were cultured in plate with various concentrations of $\mathrm{H}_{2} \mathrm{O}_{2}$. After being treated for $3 \mathrm{~h}, 10 \mu \mathrm{l}$ of MTT $(5 \mathrm{mg} / \mathrm{ml})$ was added to each well and the plates were incubated for $4 \mathrm{~h}$ at $37^{\circ} \mathrm{C}$ in $5 \% \mathrm{CO}_{2}$. Then the culture medium was removed and the blue formazan of each well was dissolved with $200 \mu 1$ dimethyl sulfoxide (DMSO). The OD value was measured at $490 \mathrm{~nm}$ using a microplate reader (Bio-Rad Model 550, Redmond, WA, USA).

Acridine orangelethidium bromide (AO/EB) double staining . ECFCs were seeded into 96 -well plates for $24 \mathrm{~h}$. Subsequently, they were treated with $\mathrm{H}_{2} \mathrm{O}_{2}$ or PBS for $3 \mathrm{~h}$ at $37^{\circ} \mathrm{C}$ in $5 \%$ $\mathrm{CO}_{2}$ followed by $\mathrm{AO} / \mathrm{EB}$ double staining as previously described (20). The cells were examined under a fluorescence microscope at $\times 200$ magnification with a 470/40 nm excitation filter (Olympus, Japan) and took photographs. Cells with condensed, fragmented nuclei were scored as apoptotic. In each experiment, at least 300 cells from several random fields were counted and the percentage of apoptotic cells was calculated as the number of apoptotic cells/300 x 100\%. The experiment was repeated three times.

Tube formation assay. After treatment with $\mathrm{H}_{2} \mathrm{O}_{2}$ or PBS for $3 \mathrm{~h}$, the ECFCs were trypsinized and seeded at 15,000 cells/well onto 96-well plates coated with $50 \mu \mathrm{l}$ growth factor-reduced Matrigel (BD Biosciences). At $24 \mathrm{~h}$, the enclosed networks of complete tubes were counted and images were collected using an Olympus inverted microscope (Olympus). The number of closed network units and tubular length of the cell were measured using the Image-Pro Plus software. Each experiment was performed in triplicate.

Protein sample preparation. After treatment, ECFCs were collected and washed with sucrose buffer (10 mM Tris, $250 \mathrm{mM}$ sucrose, $\mathrm{pH} 8.8$ ). The total protein was extracted in lysis buffer containing $7 \mathrm{M}$ urea, $2 \mathrm{M}$ thiourea, 4\% CHAPS, $30 \mathrm{mM}$ Tris, $1 \%$ protease inhibitor and $1 \%$ nuclease mix. After centrifuging the homogenate at $25,000 \mathrm{x}$ g for $30 \mathrm{~min}$, the supernatant was collected. According to the manufacturer's instructions, the protein samples were cleaned and quanti- fied with the clean-up kit and the 2D-Quant kit (Amersham Biosciences-GE Healthcare, Uppsala, Sweden), respectively.

2D-gel electrophoresis of DNP-derivatization, western blotting and image analysis. The 2D-gel electrophoresis of 2,4-dinitrophenylhydrazine (DNP)-derivatization and western blotting were performed using protocols described previously with minor modifications (21). Briefly, the sample was pooled and then rehydration buffer (7 $\mathrm{M}$ urea, $2 \mathrm{M}$ thiourea, 2\% CHAPS, $0.4 \%$ IPG buffer, $0.28 \%$ DTT and $0.4 \%$ bromophenol blue) were added to obtain a final volume of $250 \mathrm{ml}$. Next, isoelectric focusing (IEF) was conducted using an IPGphor (Amersham) with $13 \mathrm{~cm} \mathrm{pH} \mathrm{4.0-7.0} \mathrm{IPG} \mathrm{gel} \mathrm{strips} \mathrm{at} 20^{\circ} \mathrm{C}$. IEF parameters were $6 \mathrm{~h}$ at $0 \mathrm{~V}$ for rehydration, $6 \mathrm{~h}$ at $30 \mathrm{~V}$ for rehydration, $1 \mathrm{~h}$ at $500 \mathrm{~V}, 1 \mathrm{~h}$ at $1,000 \mathrm{~V}, 1 \mathrm{~h}$ at $8,000 \mathrm{~V}$ and $7 \mathrm{~h}$ at 8,000 V. Following sample rehydration and IEF, the IPG strips were placed in $15 \mathrm{ml}$ test tubes and incubated in $2 \mathrm{~N} \mathrm{HCl}$ with $20 \mathrm{mM} \mathrm{DNP}$ at $25^{\circ} \mathrm{C}$ for $20 \mathrm{~min}$. After the reaction, the samples were washed with $2 \mathrm{M}$ Tris-base $/ 30 \%$ glycerol for $15 \mathrm{~min}$. After equilibration and alkylation of strips, the second dimension was performed in a Hoefer SE600 Ruby (Amersham) using $10 \mathrm{~mA} / \mathrm{gel}$ for $1 \mathrm{~h}$ and $25 \mathrm{~mA} / \mathrm{gel}$ for $4 \mathrm{~h}$. The gel running was stopped when the bromophenol blue front reached the bottom of the gel. Then the proteins in the gel were electroblotted to PVDF using the Bio-Rad semi-dry transfer system.

The PVDF membranes were removed from the Bio-Rad semi-dry transfer system and incubated for $1 \mathrm{~h}$ with $3 \%$ BSA $(\mathrm{w} / \mathrm{v})$ dissolved in TBS and Tween-20 (0.1\%). The membranes were washed three times for $15 \mathrm{~min}$ each in TBS-Tween-20. Membranes were incubated overnight at $4^{\circ} \mathrm{C}$ with anti-DNP primary antibody (Molecular Probes, Eugene, OR, USA) at 1:200 dilution. After three washes (15 min/each) with TBS-Tween-20 solution, the membranes were incubated for $1 \mathrm{~h}$ at $4^{\circ} \mathrm{C}$ with the goat anti-rabbit Cy5-linked secondary antibody (Sigma, St. Louis, MO, USA) at a 1:5,000 dilution. Then the membranes were washed 3 times $(15 \mathrm{~min} / \mathrm{each})$ in TBS-Tween-20 solution. The membranes were scanned with a Typhoon 9400 laser scanner (Amersham) at a resolution of $100 \mathrm{~mm}$. The images of membranes were analyzed using 2D-Evolution Analysis software (Amersham) according to the protocols provided by the manufacturer.

MALDI-TOF/TOF MS and protein identification. Another two preparative gels of the control and $\mathrm{H}_{2} \mathrm{O}_{2}$-treated groups were made with $600 \mu \mathrm{g}$ protein using the same methods and conditions as described above, followed by staining with PhastGel Blue. Spots of interest that were excised from preparative gels were treated with the Ettan Spot Picker (Amersham Biosciences-GE Healthcare) for further identification.

Protein spots which were excised from the preparative gels and destained with $100 \mathrm{mM} \mathrm{NH} \mathrm{HCO}_{3}$ in $30 \%$ acetonitrile (ACN). After removing the destaining buffer, the gel pieces were lyophilized and rehydrated in $30 \mu \mathrm{l}$ of $50 \mathrm{mM} \mathrm{NH}_{4} \mathrm{HCO}_{3}$ containing $50 \mathrm{ng}$ trypsin (sequencing grade; Promega, Madison, WI, USA). After overnight digestion at $37^{\circ} \mathrm{C}$, the peptides were extracted three times with $0.1 \%$ trifluoroacetic acid in $60 \%$ ACN. Extracts were pooled together and lyophilized. The resulting lyophilized tryptic peptides were kept at $-80^{\circ} \mathrm{C}$ until mass spectrometric analysis. A protein-free gel 
A

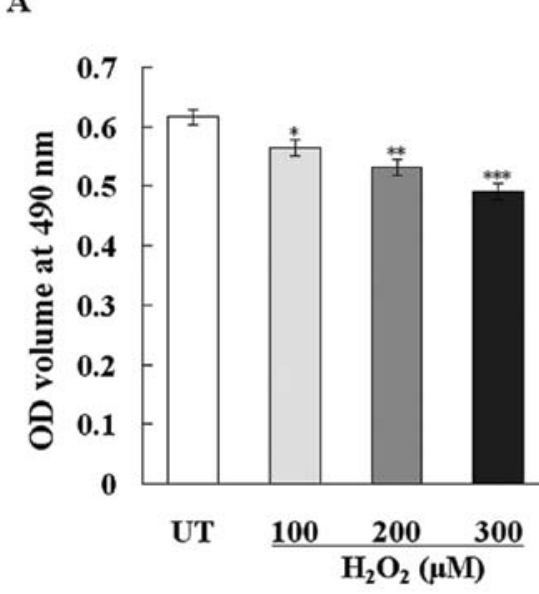

B

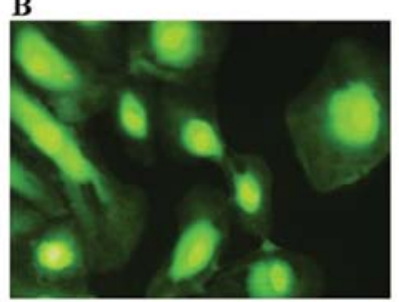

UT

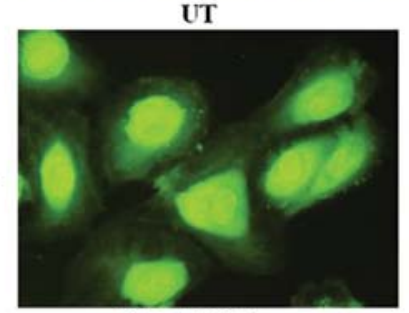

$200 \mu \mathrm{M} \mathrm{H}_{2} \mathrm{O}_{2}$

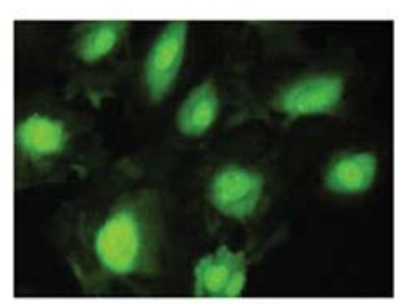

$100 \mu \mathrm{I} \mathrm{H}_{2} \mathrm{O}_{2}$

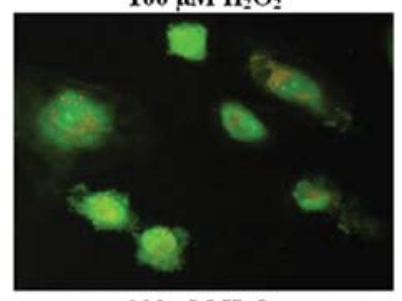

$300 \mu \mathrm{M} \mathrm{H} \mathrm{H}_{2} \mathrm{O}_{2}$

Figure 1. Effect of $\mathrm{H}_{2} \mathrm{O}_{2}$ on ECFCs proliferation and apoptosis. $\mathrm{H}_{2} \mathrm{O}_{2}$ inhibited proliferative ability and increased apoptosis in ECFCs in a dose-dependent manner. (A) OD volume of ECFCs untreated (UT) or treated by $\mathrm{H}_{2} \mathrm{O}_{2}$ for $3 \mathrm{~h}$. Results represent the mean $\pm \mathrm{SD}$ ( $\mathrm{n}=3$; ${ }^{*} \mathrm{P}<0.001 \mathrm{vs}$. untreated group; ${ }^{* *} \mathrm{P}<0.004$ vs. $100 \mu \mathrm{M} \mathrm{H}_{2} \mathrm{O}_{2}$ group; and ${ }^{* * *} \mathrm{P}<0.004$ vs. $200 \mu \mathrm{M} \mathrm{H}_{2} \mathrm{O}_{2}$ group). (B) Fluorescence micrographs showed apoptosis of ECFCs stained with AE/OB double staining.

piece was treated as above and used for a control to identify autoproteolysis products derived from trypsin.

MS and MS/MS spectra were obtained using the ABI 4800 Proteomics Analyzer MALDI TOF/TOF (Applied Biosystems, Foster City, CA, USA) operating in a result-dependent acquisition mode. Peptide mass maps were acquired in positive ion reflector mode (20 kV accelerating voltage) with 1,000 laser shots/spectrum. Monoisotopic peak masses were automatically determined within the mass range 800-4,000 Da with a signal to noise ratio minimum set to 10 and a local noise window width of $\mathrm{m} / \mathrm{z} 250$. Up to 10 of the most intense ions with a minimum signal to noise ratio $>50$ were selected as precursors for the MS/MS acquisition, excluding common trypsin autolysis peaks and matrix ion signals. In the MS/MS positive ion mode, spectra were averaged, collision energy was $2 \mathrm{kV}$, and default calibration was set. Monoisotopic peak masses were automatically determined with a signal to noise ratio minimum set to 5 and a local noise window width of $\mathrm{m} / \mathrm{z} 250$. The MS together with MS/MS spectra were searched against the UniprotKB/SwissProt database (SwissProt 56.9) using the software GPS Explorer, version 3.6 (Applied Biosystems) and MASCOT version 2.1 (Matrix Science) with the following parameter settings: trypsin cleavage, one missed cleavage allowed, carbamidomethylation set as fixed modification, oxidation of methionines allowed as variable modification, peptide mass tolerance set to $100 \mathrm{ppm}$, fragment tolerance set to $\pm 0.3 \mathrm{Da}$ and minimum ion score confidence interval for MS/MS data set to $95 \%$.

Statistical analysis. Data are expressed in means \pm standard deviation (SD) and analyzed with SPSS 17.0 statistical software. Differences between groups were tested with an independent-sample t-test. A P-value $<0.05$ was considered to denote statistical significant differences.

\section{Results}

$\mathrm{H}_{2} \mathrm{O}_{2}$ inhibits proliferation and increases apoptosis in ECFCs. The MTT assay demonstrated that $\mathrm{H}_{2} \mathrm{O}_{2}$ treatment led to a decreased proliferation of ECFCs in a dose-dependent manner. The cell survival rates were $90.57 \pm 6.40,85.06 \pm 6.00$ and $79.96 \pm 3.79 \%$ when cells were treated with $\mathrm{H}_{2} \mathrm{O}_{2}$ at concentrations of 100, 200 and $300 \mu \mathrm{M}$, respectively (Fig. 1A). AO/EB double staining is one of most reliable method for determining cell apoptosis. It makes possible to perform high-quality studies of cell morphology and to distinguish viable from early and late stage apoptotic (20). The result of AO/EB double fluorescent staining showed that the apoptosis of ECFCs induced by $\mathrm{H}_{2} \mathrm{O}_{2}$ treatment was dose-dependent (Fig. 1B). The cell apoptotic rates were $1.33,8.67,12.33$ and $20.00 \%$ when ECFCs were treated with $\mathrm{H}_{2} \mathrm{O}_{2}$ at concentrations of $0,100,200$ and $300 \mu \mathrm{M}$, respectively.

Oxidant stress impairs the tube-forming ability of ECFCs. Capability of tube-forming is the most important property of ECFCs and network formation using Matrigel is a simple and reliable method in vitro. To test the effect of $\mathrm{H}_{2} \mathrm{O}_{2}$ on the tube forming ability of ECFCs, we used Matrigel assays with an observation time point of $24 \mathrm{~h}$. (Fig. 2A). Compared with the group untreated by $\mathrm{H}_{2} \mathrm{O}_{2}$, the groups pretreated with $\mathrm{H}_{2} \mathrm{O}_{2}$ for 3 h exhibited significant reduction in number of closed network units and total tubular length. (Fig. 2B and C). Moreover, there was no closed network unit forming at the $300 \mu \mathrm{M} \mathrm{H}_{2} \mathrm{O}_{2}$ concentration. These data imply that the capability of forming tubules of ECFCs diminishes due to the oxidative stress.

Analysis of oxidative levels of proteins and identification of proteins. Oxidative modification of proteins induced by reactive oxygen species is the formation of protein carbonyls which can react with DNP. So the oxidative levels of ECFCs proteins can be measured by detecting the content of DNP, which can be obtained by determining the intensity of fluorescence linked to the secondary antibody on the membranes. After analysis by 2D-Evolution software, protein spots which have at least triple differences in oxidative levels on different membranes were considered for further quantitative analysis. According to the statistics, 8 protein spots were found to have 


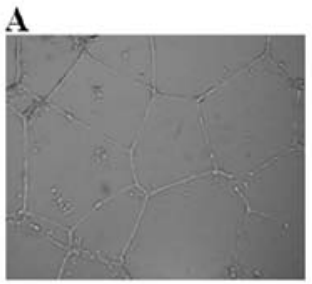

UT

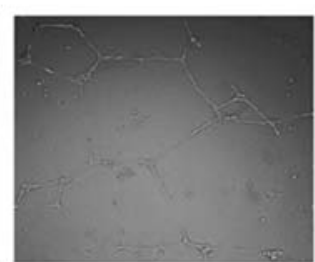

$100 \mathrm{MM} \mathrm{H}_{2} \mathrm{O}_{2}$

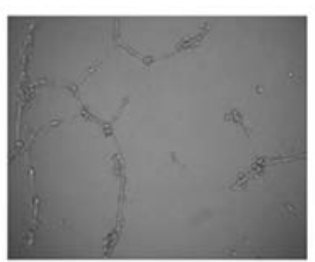

$200 \mu \mathrm{M} \mathrm{H}_{2} \mathrm{O}_{2}$

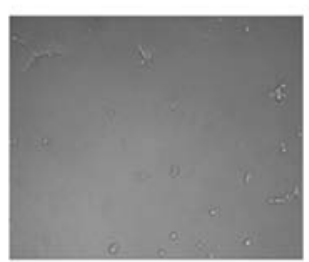

$300 \mu \mathrm{M} \mathrm{H}_{2} \mathrm{O}_{2}$
B

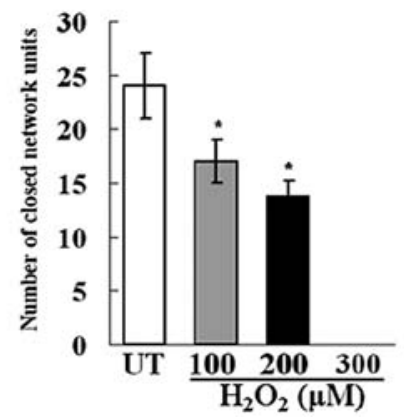

C

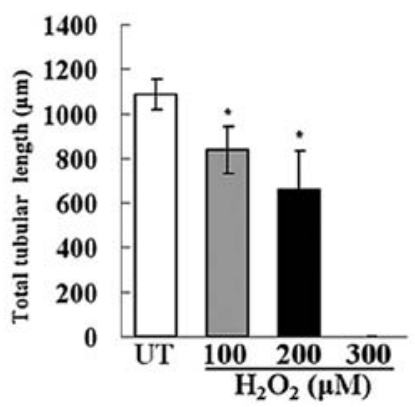

Figure 2. Effect of $\mathrm{H}_{2} \mathrm{O}_{2}$ on tube forming ability of ECFCs. ECFCs untreated (UT) or pretreated by an increasing concentrations of $\mathrm{H}_{2} \mathrm{O}_{2}$ for $3 \mathrm{~h}$ were seeded in the Matrigel and then incubated for another $24 \mathrm{~h}$. (A) Photomicrographs (magnification, x100) of network formed by ECFCs $24 \mathrm{~h}$ following no treatment or pretreatment with increasing concentrations of $\mathrm{H}_{2} \mathrm{O}_{2}$ for $3 \mathrm{~h}$. (B) Quantitation of vessel density. Data represent the average number of closed network units per central visual field of each well $\pm \mathrm{SD}\left(\mathrm{n}=3\right.$; ${ }^{*} \mathrm{P}<0.03$ vs. untreated group). There was no closed nework forming detected at $300 \mu \mathrm{M} \mathrm{H} \mathrm{H}_{2} \mathrm{O}_{2}$. (C) Quantitation of total tubular length. Data represent the average total capillary vessel length per picture obtained $\pm \mathrm{SD}\left(\mathrm{n}=3,{ }^{*} \mathrm{P}<0.03\right.$ vs. untreated group). There was no vessel forming detected at $300 \mu \mathrm{M}$.
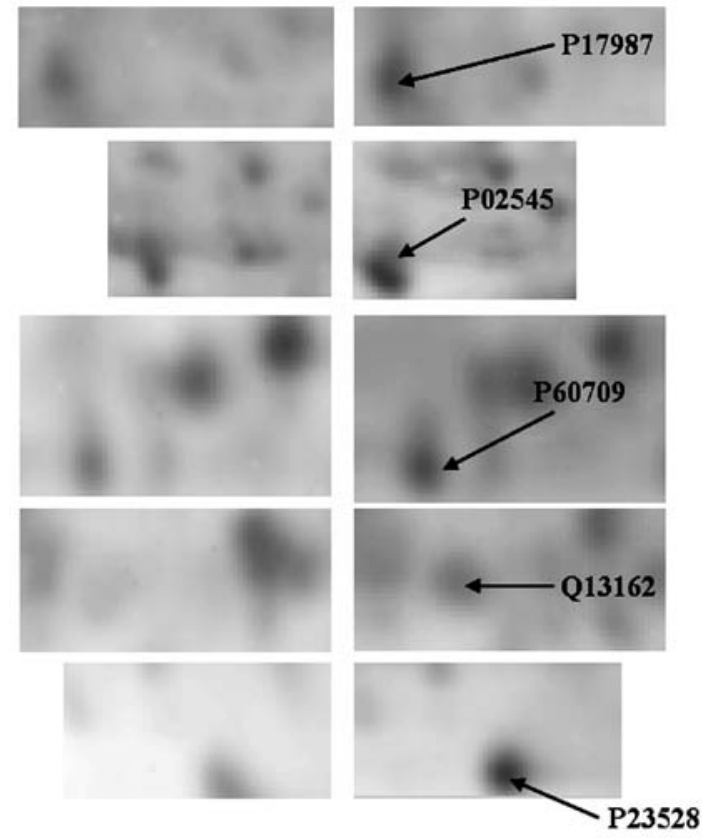

Figure 3. 2D-Oxyblot membrane images of protein spots with different oxidative levels. Spots representing proteins with upregulated oxidative levels in the untreated group (left) vs. $\mathrm{H}_{2} \mathrm{O}_{2}$-treated group (right).

differentially expressed oxidative levels, of which 5 were increased and 3 decreased (Fig. 3).

Protein spots used for MALDI TOF/TOF mass spectrometry analysis were excised from 2D-gels obtained with non-DNPtreated samples (Fig. 4). The peptide mass peaks and peptide sequences were compared with those in the Swiss Prot database. The protein identification was further verified by searching the NCBI protein database. As a result, 5 proteins with upregulated

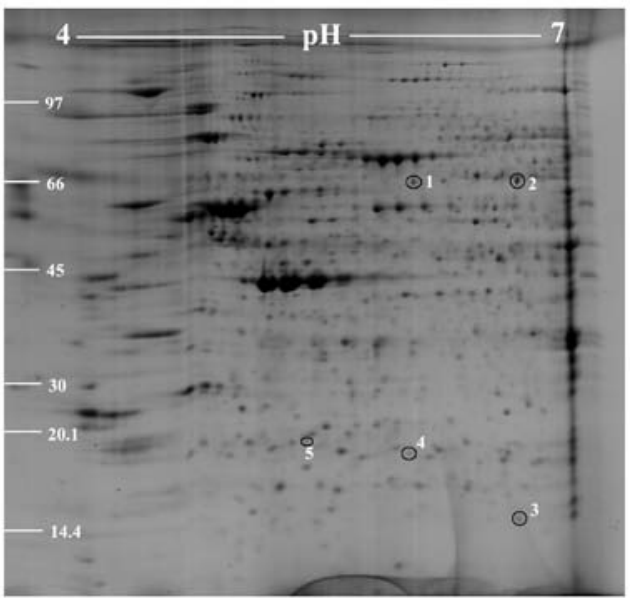

Figure 4. Image from Coomassie brilliant blue stained 2-DE gel of five protein spots with upregulated oxidative levels: 1, T-complex protein 1 subunit $\alpha$; 2 , isoform A of prelamin-A/C; 3 , cofilin-1; 4, peroxiredoxin- 4 ; 5 , actin.

oxidative levels were identified successfully. They were the T-complex protein 1 subunit $\alpha$, isoform $\mathrm{A}$ of prelamin-A/C, cofilin-1, peroxiredoxin-4 and actin (Fig. 4 and Table I).

\section{Discussion}

Endothelial progenitor cells (EPCs) have been proven to play an important role in neovascularization and to be biomarkers for cardiovascular disease risk $(3,22)$. Impaired function of EPCs is related to endothelial dysfunction (23). Some studies have indicated that EPCs are involved in repair of damaged endothelium and attenuate the development of atherosclerosis (24-26). Several pathological conditions, including hypertension, 
Table I. Information of identified proteins with upregulated oxidative levels in $\mathrm{H}_{2} \mathrm{O}_{2}$-treated ECFCs.

\begin{tabular}{llccc}
\hline Spot no. & \multicolumn{1}{c}{ Protein identified } & SwissProt Accession no. & pI/Mr (kDa) & MASCOT score \\
\hline 1 & T-complex protein 1 subunit $\alpha$ & $\mathrm{P} 17987$ & $5.80 / 60.82$ & 689 \\
2 & Isoform A of prelamin-A/C & $\mathrm{P} 02545$ & $6.57 / 74.38$ & 177 \\
3 & Cofilin-1 & $\mathrm{P} 23528$ & $6.29 / 18.72$ & 107 \\
4 & Peroxiredoxin-4 & $\mathrm{Q} 13162$ & $5.86 / 30.75$ & 123 \\
5 & Actin & P60709 & $5.29 / 42.05$ & 413 \\
\hline
\end{tabular}

diabetes, and atherosclerosis, can impair the endothelial cell by oxidative stress (27). EPCs are exposed to the oxidative stress during the process of repairing endothelial cells. In the present oxidative stress model, we demonstrated that $\mathrm{H}_{2} \mathrm{O}_{2}$ treatment led to a decreased proliferation and increased apoptosis of ECFCs in a dose-dependent manner, which is consistent with results of a previous study (17). In addition the capability of forming tubules by ECFCs was impaired due to oxidative stress. Five proteins with upregulated oxidative levels were identified successfully. Based on this, we applied a novel proteomics analysis of oxidative modification to investigate alterations in oxidative levels of proteins associated with $\mathrm{H}_{2} \mathrm{O}_{2}$-induced morphologic changes in ECFCs. To the best of our knowledge, this is the first proteomics analysis of oxidative modification for $\mathrm{H}_{2} \mathrm{O}_{2}$-induced ECFCs. Our results may provide novel insight into the proteinic mechanisms of oxidative stress on ECFCs.

Molecular chaperones are a group of proteins that assist in the folding and assembly of other proteins. Many of them work by recognizing misfolded or partially folded proteins via exposed hydrophobic regions. This provides the cell with a general mechanism for rescuing non-native proteins before irreversible aggregation occurs. Accumulation of misfolding proteins has the potential to induce cellular damage (28). TCP-1, as the eukaryotic cytoplasmic molecular chaperone consisting of eight subunit species, is not only a uniquely complex chaperonin directly involved in actin and tubulin cytoskeletal protein folding but also required for the production of native actin and tubulin (29,30). Though the actin and tubulin monomers have very different native structures, they both need to interact with TCP-1 in order to reach their native states (31).

Tube formation in vitro, can be blocked by colchicine or cytochalasin, indicating that both microfilaments and microtubules (composed of actin and tubulin, respectively) are involved in this process. One of the important steps involves the reorganization of the cytoskeleton into bundles of actin filaments oriented along the axis of the tubes located at the periphery of the cells (32). It has been shown that actin oxidation can result in changes in cytoskeleton organization and dynamics (33). Our data showed that oxidative levels of TCP-1 and actin were significantly increased after $\mathrm{H}_{2} \mathrm{O}_{2}$ treatment. In addition, the tube-forming ability of ECFCs was impaired in the $\mathrm{H}_{2} \mathrm{O}_{2}$-treated group. Thus the oxidative modification of TCP-1 and actin may lead to the misfolding of cytoskeletal protein and changes in cytoskeleton organization. All of these factors may be responsible for the impaired tube-forming ability of ECFCs induced by oxidative stress.

Cofilin is an actin-binding protein that is considered to be a key regulator of the dynamic reorganization of the actin cytoskeleton. The binding of cofilin to actin leads to depolymerization of actin filaments. Under physiological conditions, cofilin plays an important role in the regulation of cell morphology and cytoskeletal organization (34). When cofilin is oxidized, its conformation changes and it is no longer able to depolymerize actin filaments, though it still associates with F-actin (35). The inability of oxidized cofilin leads to the dysregulation of actin cytoskeleton dynamics.

Apoptosis is a complex process related to mitochondrial integrity. It has been shown that cofilin is a key target of oxidation. Oxidation of cofilin causes it to dissociate from actin and translocate to the mitochondria, where it induces swelling and the release of cytochrome $\mathrm{C}$. When oxidation of this single regulatory protein is prevented, apoptosis induced by oxidative stress is inhibited $(36,37)$. Cofilin has been regarded as a death-inducing agent that acts on the mitochondria in oxidantinduced apoptosis. In this study, the result of proteomics analysis showed that oxidative levels of cofilin were higher in the $\mathrm{H}_{2} \mathrm{O}_{2}$ group than in the untreated group. As discussed above, oxidation of cofilin can cause an abnormality in cytoskeleton reorganization and mitochondria. These may account in part for increased apoptosis and the impaired tube-forming ability of ECFCs induced by $\mathrm{H}_{2} \mathrm{O}_{2}$ treatment.

The lamina is important for the integrity of the nucleus and has a central role in defining interphase nuclear organization. Defects in lamin can contribute to or directly cause human diseases (38). Under physiological conditions, mature lamin A is produced by a series of post-translational processing steps performed on prelamin A. In vitro, accumulation of prelamin A can cause nuclear morphology defect, premature senescence and failure to repair DNA (39-41). In vascular diseases, accumulation of prelamin $\mathrm{A}$ accelerates senescence in atherosclerotic plaques by interfering with DNA damage repair and mitosis (42). Dysfunctions of vascular endothelial and smooth muscle cells were also shown to be related to prelamin A accumulation at the cellular and nuclear levels $(39,43,44)$. Under the condition of oxidative stress, downregulation of FACE1 can lead to accumulation of prelamin A potentiation which causes DNA damage, mitotic catastrophe and premature senescence (45). In the present study, we found an increased oxidative level of prelamin A in ECFCs subjected to $\mathrm{H}_{2} \mathrm{O}_{2}$ induced oxidative stress. We thus speculate that accumulation of prelamin A may also occur in the increased apoptosis of ECFCs introduced by $\mathrm{H}_{2} \mathrm{O}_{2}$.

In eukaryotes, $\mathrm{H}_{2} \mathrm{O}_{2}$ was generated by disulfide bond formation driven through the Erol/PDI (protein disulfideisomerase) system in the endoplasmic reticulum (46). Among the various peroxidases distributed in the cytosol, perox- 
iredoxin-4 (Prx4) is the only peroxiredoxin family protein residing in the endoplasmic reticulum $(47,48)$. Prx4 plays an important role not only in peroxide defense, but also in regulating peroxide-mediated cell signaling. Spermatogenic cells were reported to be more susceptible to cell death via oxidative damage in Prx4-knockout mice (49). Prx4 protects cells from oxidative stress by metabolizing Ero1-generated $\mathrm{H}_{2} \mathrm{O}_{2}$ and overoxidation of Prx 4 can be caused by increased Erol activity in cells (50). Though Prx4 has a high reactivity with $\mathrm{H}_{2} \mathrm{O}_{2}$, it is susceptible to overoxidation which would result in irreversible inactivation of Prx4. In the present study, the oxidative level of Prx4 was observed to be significantly upregulated in the $\mathrm{H}_{2} \mathrm{O}_{2}$-treatment group, though there was base oxidation in the untreated group. The inactivation of Prx 4 caused by overoxidation may partly explain the oxidative damage of ECFCs induced by $\mathrm{H}_{2} \mathrm{O}_{2}$.

In conclusion, this study showed that ECFCs treated by $\mathrm{H}_{2} \mathrm{O}_{2}$ exhibited altered oxidative levels of five proteins. The upregulated oxidative levels of these five proteins may be responsible for the dysfunction of ECFCs including decreased cell proliferation, increased apoptosis and the impaired capability of forming tubules. Growing evidence indicates that oxidative stress under pathophysiologic conditions is the unifying mechanism for the development of cardiovascular diseases. ECFCs are considered to have great potential for promoting the vascular repair. So it is very important to investigate the effect of oxidative stress on ECFCs. Though, to our best knowledge, this is the first redox proteomics analysis on the oxidative levels of proteins in ECFCs treated by $\mathrm{H}_{2} \mathrm{O}_{2}$, research on the exact mechanisms is needed. Further research could contribute to a better understanding of vascular diseases caused by oxidative stress and may supply some useful clues or targets for clinical therapy.

\section{References}

1. Xu Q: Mouse models of arteriosclerosis: from arterial injuries to vascular grafts. Am J Pathol 165: 1-10, 2004.

2. Ross R: Atherosclerosis-an inflammatory disease. N Engl J Med 340: 115-126, 1999.

3. Vasa M, Fichtlscherer S, Aicher A, Adler K, Urbich C, Martin H, Zeiher AM and Dimmeler S: Number and migratory activity of circulating endothelial progenitor cells inversely correlate with risk factors for coronary artery disease. Circ Res 89: E1-E7, 2001.

4. Asahara T, Murohara T, Sullivan A, Silver M, van der Zee R, Li T, Witzenbichler B, Schatteman G and Isner JM: Isolation of putative progenitor endothelial cells for angiogenesis. Science 275: 964-967, 1997.

5. Kong D, Melo LG, Gnecchi M, Zhang L, Mostoslavsky G, Liew CC, Pratt RE and Dzau VJ: Cytokine-induced mobilization of circulating endothelial progenitor cells enhances repair of injured arteries. Circulation 110: 2039-2046, 2004.

6. Hu Y, Davison F, Zhang Z and Xu Q: Endothelial replacement and angiogenesis in arteriosclerotic lesions of allografts are contributed by circulating progenitor cells. Circulation 108: 3122-3127, 2003.

7. Xu Q, Zhang Z, Davison F and Hu Y: Circulating progenitor cells regenerate endothelium of vein graft atherosclerosis, which is diminished in ApoE-deficient mice. Circ Res 93: e76-e86, 2003.

8. He T, Smith LA, Harrington S, Nath KA, Caplice NM and Katusic ZS: Transplantation of circulating endothelial progenitor cells restores endothelial function of denuded rabbit carotid arteries. Stroke 35: 2378-2384, 2004.

9. Rauscher FM, Goldschmidt-Clermont PJ, Davis BH, Wang T, Gregg D, Ramaswami P, Pippen AM, Annex BH, Dong C and Taylor DA: Aging, progenitor cell exhaustion, and atherosclerosis. Circulation 108: 457-463, 2003.
10. Flores-Ramírez R, Uribe-Longoria A, Rangel-Fuentes MM, Gutiérrez-Fajardo P, Salazar-Riojas R, Cervantes-García D, Treviño-Ortiz JH, Benavides-Chereti GJ, Espinosa-Oliveros LP, Limón-Rodríguez $\mathrm{RH}$, et al: Intracoronary infusion of $\mathrm{CD}_{133^{+}}$ endothelial progenitor cells improves heart function and quality of life in patients with chronic post infarct heart insufficiency. Cardiovasc Revasc Med 11: 72-78, 2010.

11. Vasa M, Fichtlscherer S, Adler K, Aicher A, Martin H,Zeiher AM and Dimmeler S: Increase in circulating endothelial progenitor cells by statin therapy in patients with stable coronary artery disease. Circulation 103: 2885-2890, 2001.

12. Hill JM, Zalos G, Halcox JP, Schenke WH, Waclawiw MA, Quyyumi AA and Finkel T: Circulating endothelial progenitor cells, vascular function, and cardiovascular risk. N Engl J Med 348: 593-600, 2003.

13. Werner N, Kosiol S, Schiegl T, Ahlers P, Walenta K, Link A, Böhm $\mathrm{M}$ and Nickenig G: Circulating endothelial progenitor cells and cardiovascular outcomes. N Engl J Med 353: 999-1007, 2005.

14. Griendling KK and FitzGerald GA: Oxidative stress and cardiovascular injury. Part II: animal and human studies. Circulation 108: 2034-2040, 2003

15. Dernbach E, Urbich C, Brandes RP, Hofmann WK, Zeiher AM and Dimmeler S: Antioxidative stress-associated genes in circulating progenitor cells: evidence for enhanced resistance against oxidative stress. Blood 104: 3591-3597, 2004.

16. He T, Peterson TE, Holmuhamedov EL, Terzic A, Caplice NM, Oberley LW and Katusic ZS: Human endothelial progenitor cells tolerate oxidative stress due to intrinsically high expression of manganese superoxide dismutase. Arterioscler Thromb Vasc Biol 24: 2021-2027, 2004.

17. Ingram DA, Krier TR, Mead LE, McGuire C, Prater DN, Bhavsar J, Saadatzadeh MR, Bijangi-Vishehsaraei K, Li F, Yoder MC and Haneline LS: Clonogenic endothelial progenitor cells are sensitive to oxidative stress. Stem Cells 25: 297-304, 2007.

18. Yoder MC, Mead LE, Prater D, Krier TR, Mroueh KN, Li F, Krasich R, Temm CJ, Prchal JT and Ingram DA: Redefining endothelial progenitor cells via clonal analysis and hematopoietic stem/progenitor cell principals. Blood 109: 1801-1809, 2007.

19. Sieveking DP, Buckle A, Celermajer DS and Ng MK: Strikingly different angiogenic properties of endothelial progenitor cell subpopulations: insights from a novel human angiogenesis assay. J Am Coll Cardiol 51: 660-668, 2008.

20. Popovic S, Arsenijevic N and Baskic D: In vitro assay for the quantitative measurement of apoptotic lymphocytes phagocytosis by peripheral blood monocytes. Acta Physiol Hung 93: 325-333, 2006.

21. Conrad CC, Choi J, Malakowsky CA, Talent JM, Dai R, Marshall P and Gracy RW: Identification of protein carbonyls after twodimensional electrophoresis. Proteomics 1: 829-834, 2001.

22. Rafii S and Lyden D: Therapeutic stem and progenitor cell transplantation for organ vascularization and regeneration. Nat Med 9: 702-712, 2003.

23. Galasso G, Schiekofer S, Sato K, Shibata R, Handy DE, Ouchi N, Leopold JA, Loscalzo J and Walsh K: Impaired angiogenesis in glutathione peroxidase-1-deficient mice is associated with endothelial progenitor cell dysfunction. Circ Res 98: 254-261, 2006.

24. Walter DH, Rittig K, Bahlmann FH, Kirchmair R, Silver M, Murayama T, Nishimura H, Losordo DW, Asahara T and Isner JM: Statin therapy accelerates re- endothelialization: a novel effect involving mobilization and incorporation of bone marrow-derived endothelial progenitor cells. Circulation 105: 3017-3024, 2002.

25. Werner N, Junk S, Laufs U, Link A, Walenta K, Bohm M and Nickenig G: Intravenous transfusion of endothelial progenitor cells reduces neointima formation after vascular injury. Circ Res 93: e17-e24, 2003.

26. Xiao Q, Kiechl S, Patel S, Oberhollenzer F, Weger S, Mayr A, Metzler B, Reindl M, Hu Y, Willeit J and Xu Q: Endothelial progenitor cells, cardiovascular risk factors, cytokine levels and atherosclerosis-results from a large population-based study. PLoS One 2: e975, 2007.

27. Ogita $\mathrm{H}$ and Liao J: Endothelial function and oxidative stress. Endothelium 11: 123-132, 2004.

28. Brackley KI and Grantham J: Activities of the chaperonin containing TCP-1 (CCT): implications for cell cycle progression and cytoskeletal organisation. Cell Stress Chaperones 14: 23-31, 2009.

29. Valpuesta JM, Martín-Benito J, Gómez-Puertas P, Carrascosa JL and Willison KR: Structure and function of a protein folding machine: the eukaryotic cytosolic chaperonin CCT. FEBS Lett 529: $11-16,2002$ 
30. Horwich AL, Fenton WA, Chapman E and Farr GW: Two families of chaperonin: physiology and mechanism. Annu Rev Cell Dev Biol 23: 115-145, 2007.

31. Lewis SA, Tian G and Cowan NJ: The alpha- and beta-tubulin folding pathways. Trends Cell Biol 7: 479-484, 1997.

32. Grant DS, Lelkes PI, Fukuda K and Kleinman HK: Intracellular mechanisms involved in basement membrane induced blood vessel differentiation in vitro. In Vitro Cell Dev Biol 27A: 327-336, 1991.

33. Dalle-Donne I, Rossi R, Giustarini D, Gagliano N, Lusini L, Milzani A, Di Simplicio P and Colombo R: Actin carbonylation: from a simple marker of protein oxidation to relevant signs of severe functional impairment. Free Radic Biol Med 31: 1075-1083, 2001.

34. Samstag Y, Eibert SM, Klemke M and Wabnitz GH: Actin cytoskeletal dynamics in $\mathrm{T}$ lymphocyte activation and migration. J Leukoc Biol 73: 30-48, 2003.

35. Klemke M, Wabnitz GH, Funke F, Funk B, Kirchgessner H and Samstag Y: Oxidation of cofilin mediates T cell hyporesponsiveness under oxidative stress conditions. Immunity 29: 404-413, 2008 .

36. Klamt F, Zdanov S, Levine RL, Pariser A, Zhang Y, Zhang B, Yu LR, Veenstra TD and Shacter E: Oxidant-induced apoptosis is mediated by oxidation of the actin-regulatory protein cofilin. Nat Cell Biol 11: 1241-1246, 2009.

37. Wabnitz GH, Goursot C, Jahraus B, Kirchgessner H, Hellwig A, Klemke M, Konstandin MH and Samstag Y: Mitochondrial translocation of oxidized cofilin induces caspase-independent necrotic-like programmed cell death of T cells. Cell Death Dis 1: e58, 2010.

38. Goldman RD, Gruenbaum Y, Moir RD, Shumaker DK and Spann TP: Nuclear lamins: building blocks of nuclear architecture. Genes Dev 16: 533-547, 2002.

39. Goldman RD, Shumaker DK, Erdos MR, Eriksson M, Goldman AE, Gordon LB, Gruenbaum Y, Khuon S, Mendez M, Varga R and Collins FS: Accumulation of mutant lamin A causes progressive changes in nuclear architecture in Hutchinson-Gilford progeria syndrome. Proc Natl Acad Sci USA 101: 8963-8968, 2004.

40. Bridger JM and Kill IR: Aging of Hutchinson-Gilford progeria syndrome fibroblasts is characterised by hyperproliferation and increased apoptosis. Exp Gerontol 39: 717-724, 2004.
41. Scaffidi P and Misteli T: Lamin A-dependent nuclear defects in human aging. Science 312: 1059-1063, 2006.

42. Matthews C, Gorenne I, Scott S, Figg N, Kirkpatrick P, Ritchie A, Goddard $\mathrm{M}$ and Bennett $\mathrm{M}$ : Vascular smooth muscle cells undergo telomere-based senescence in human atherosclerosis: effects of telomerase and oxidative stress. Circ Res 99: 156-164, 2006.

43. McClintock D, Gordon LB and Djabali K: Hutchinson-Gilford progeria mutant lamin A primarily targets human vascular cells as detected by an anti-Lamin A G608G antibody. Proc Natl Acad Sci USA 103: 2154-2159, 2006.

44. Capell BC, Erdos MR, Madigan JP, Fiordalisi JJ, Varga R, Conneely KN, Gordon LB, Der CJ, Cox AD and Collins FS: Inhibiting farnesylation of progerin prevents the characteristic nuclear blebbing of Hutchinson-Gilford progeria syndrome. Proc Natl Acad Sci USA 102: 12879-12884, 2005.

45. Ragnauth CD, Warren DT, Liu Y, McNair R, Tajsic T, Figg N, Shroff R, Skepper J and Shanahan CM: Prelamin A acts to accelerate smooth muscle cell senescence and is a novel biomarker of human vascular aging. Circulation 121: 2200-2210, 2010.

46. Wang L, Li SJ, Sidhu A, Zhu L, Liang Y, Freedman RB and Wang CC: Reconstitution of human Ero1-Lalpha/protein-disulfide isomerase oxidative folding pathway in vitro. Position-dependent differences in role between the a and a' domains of proteindisulfide isomerase. J Biol Chem 284: 199-206, 2009.

47. Rhee SG, Chae HZ and Kim K: Peroxiredoxins: a historical overview and speculative preview of novel mechanisms and emerging concepts in cell signaling. Free Radic Biol Med 38: 1543-1552, 2005.

48. Rhee SG, Kang SW, Jeong W, Chang TS, Yang KS and Woo HA: Intracellular messenger function of hydrogen peroxide and its regulation by peroxiredoxins. Curr Opin Cell Biol 17: 183-189, 2005.

49. Iuchi Y, Okada F, Tsunoda S, Kibe N, Shirasawa N, Ikawa M, Okabe M, Ikeda Y and Fujii J: Peroxiredoxin 4 knockout results in elevated spermatogenic cell death via oxidative stress. Biochem J 419: 149-158, 2009.

50. Tavender TJ and Bulleid NJ: Peroxiredoxin IV protects cells from oxidative stress by removing $\mathrm{H}_{2} \mathrm{O}_{2}$ produced during disulphide formation. J Cell Sci 123: 2672-2679, 2010. 